\title{
PERUBAHAN PERMUKIMAN NELAYAN PASCA REKLAMASI PANTAI DI KELURAHAN LETTE KECAMATAN MARISO MAKASSAR
}

\author{
Aidi Darmansyah* \\ Mahasiswa Magister Perencanaan Kota dan Daerah, Program Pascasarjana \\ Fakultas Teknik, Universitas Gadjah Mada \\ Sudaryono dan Deva Fosterharoldas Swasto \\ Jurusan Teknik Arsitektur dan Perencaan Kota dan Daerah, \\ Fakultas Teknik Universitas Gadjah Mada
}

Submitted: 31-07-2018; Revised:20-09-2018; Accepted: 25-09-2018

\begin{abstract}
Lette is one of the village in Mariso subdistrict, Makassar City which has a suburban area and the community has a livelihood as a fisherman. The condition of the coastal area and Tanjung Bunga beach has undergone a change, which used to be the territorial waters now are largely transformed into land, due to the ongoing coastal and beach reclamation process in the area of Tanjung Bunga. To meet the need for urban space, Lette fishermen have no choice but to be relocated from their place of origin to the flats. This study aims to determine the spatial, cultural, socio-economic changes in the fisherman settlement of Lette and the factors that drive those changes. This study uses an inductive-qualitative method with a phenomenological approach. The results of the study shows that the changes that occur are changes in coastal space, changes in settlement space, and the creation of a central business, tourism, and entertainment area. Factors driving those changes are changes in fishing boat entry access, dock circulation, catching areas that are not potential anymore, domestic activities, spatial space utilization, bale-bale culture, informal fishing activities, and new economic space.
\end{abstract}

Keywords: Fisherman; Lette; Phenomenology; Settlement.

\section{ABSTRAK}

Lette merupakan salah satu kelurahan di Kecamatan Mariso Kota Makassar yang mempunyai wilayah di pinggiran kota dan masyarakatnya bermatapencaharian sebagai nelayan. Kondisi wilayah pesisir dan pantai Tanjung Bunga di kelurahan Lette telah mengalami perubahan. Sebagian besar wilayah perairan sekarang telah berubah menjadi daratan. Perubahan ini terjadi karena adanya proses reklamasi pesisir dan pantai yang sedang berlangsung di wilayah Tanjung Bunga. Untuk memenuhi kebutuhan akan ruang kota, nelayan Lette tidak mempunyai pilihan selain harus direlokasi dari tempat asal mereka ke rumah susun. Penelitian ini bertujuan untuk mengetahui perubahan spasial, kultur, dan sosial ekonomi pada permukiman nelayan Lette serta faktor yang mendorong perubahan tersebut. Penelitian ini menggunakan metode induktif-kualitatif dengan pendekatan fenomenologi. Hasil penelitian menunjukkan adanya perubahan yang terjadi pada ruang pesisir dan ruang permukiman, serta terciptanya kawasan pusat bisnis, wisata, dan hiburan. Faktor yang mendorong perubahan tersebut adalah perubahan akses keluar masuk perahu nelayan, sirkulasi dermaga, area tangkap yang sudah tidak potensial, aktivitas domestik, pemanfaatan ruang spasial, budaya bale-bale, aktivitas informal nelayan, dan ruang ekonomi baru.

\section{Kata Kunci: Fenomenologi; Lette; Nelayan; Permukiman.}

${ }^{*}$ Corresponding author: archigreen76@gmail.com

Copyright@2019 THE AUTHOR(S). This article is distributed under a Creative Commons Attribution-Share Alike 4.0 International license. Jurnal Teknosains is published by the Graduate School of Universitas Gadjah Mada. 


\section{PENGANTAR}

Kota Makassar dalam dekade terakhir mengalami perkembangan sangat pesat. Pertumbuhan ekonomi dan penduduk menunjukkan tingginya dinamika kehidupan Kota Makassar sehingga membawa konsekuensi terhadap meningkatnya permintaan kebutuhan lahan di kota. Gejala Urban sprawl atau perembetan kota sudah nampak di permukaan, dan dikuatirkan dapat menyebabkan terjadinya penurunan kualitas lingkungan di kota dan wilayah pinggirannya (Ihsan, 2012). Pola Urban Sprawl menurut Oeslati dkk., 2015; Dadi dkk., 2016; Ewing dkk., 2017 dalam Giyasih (2017) yaitu (1) konsentris, (2) ribbon/linier/aksial, dan (3) pengembangan loncatan atau papan catur.

Menurut Giyasih (2017), indikasi fisik urban sprawl wilayah pertanian ditandai dengan konversi lahan pertanian ke nonpertanian. Sebelum indikasi urban sprawl ada di suatu area, penggunaan lahan didominasi oleh tutupan vegetasi. Akan tetapi, urban sprawl menyebabkan penggunaan lahan yang dominan berubah dari liputan vegetasi ke cakupan bangunan atau area terbangun. Begitu juga dengan urban sprawl wilayah pesisir laut, tentunya diindikasikan adanya konversi lahan pesisir laut menjadi permukiman.

Sifat-sifat kekotaan seperti bangunan dan jalan, kemudian akan merembet secara horizontal keluar dari inti kota ke arah wilayah pinggiran kota. Gejala perembetan kota tersebut pada akhirnya merubah wilayah alami menjadi wilayah dengan sifat kekotaan dan membawa perubahan terhadap banyak aspek di wilayah pinggiran salah satunya adalah dengan munculnya permukiman kumuh di sekitar pesisir pantai.

Fenomena permukiman kumuh di pesisir pantai di Kota Makassar salah satunya berada di Kelurahan Lette Kecamatan Mariso. Pemerintah Kota Makassar telah menerapkan serangkaian program untuk mengatasi persoalan perkembangan permukiman kumuh ini. Salah satunya melalui program relokasi permukiman nelayan. Program relokasi permukiman kumuh Melalui Direktorat Pekerjaan Umum bekerja sama dengan pemerintah Kota Makassar, merelokasi masyarakat nelayan pesisir Lette ke rumah susun. Akan tetapi, kondisi di rumah susun sangatlah berbeda dengan kondisi tempat tinggal asal karena adanya perubahan pola permukiman yang semula pola permukimannya menyebar secara horisontal di sepanjang pesisir pantai sekarang berubah menjadi vertikal di rumah susun (Gambar 1), selain harus meninggalkan tempat tinggal asal serta kenyamanan yang telah dimiliki di permukiman sebelumnya, adaptasi terhadap lingkungan baru mereka ini juga membawa potensi perubahanperubahan yang terjadi pada masyarakat Lette.

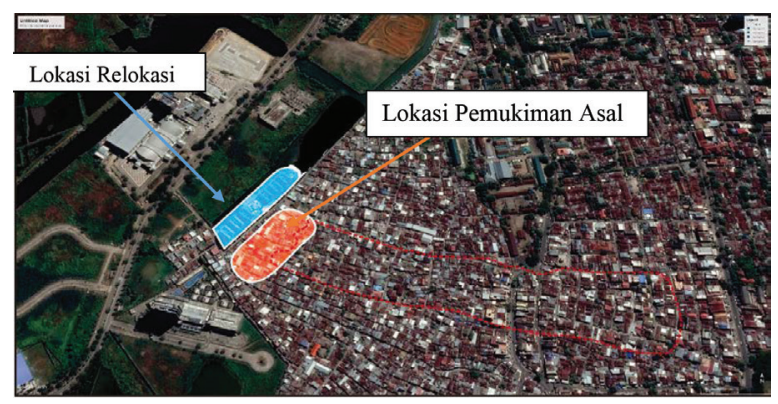

Gambar 1.

Lokasi Asal dan Lokasi Relokasi Permukiman Nelayan Sumber: Citra Google Earth, (2017)

Masyarakat nelayan merupakan masyarakat yang tinggal di wilayah pantai dan mempertahankan hidupnya dari kegiatan pengelolaan sumber daya laut (perikanan) yang tersedia. Masyarakat nelayan merupakan bagian dari masyarakat pesisir. Secara teoritis, masyarakat pesisir didefinisikan sebagai masyarakat yang tinggal dan melakukan kegiatan sosial ekonomi yang berkaitan dengan sumber daya wilayah pesisir dan lautan. Akan tetapi, secara keruangan masyarakat pesisir dapat didefinisikan sebagai masyarakat yang tinggal secara spasial di wilayah pesisir tanpa mempertimbangkan apakah mereka memiliki kegiatan sosial ekonomi yang berkaitan dengan potensi dan kondisi sumber daya pesisir dan lautan. Masyarakat pesisir memiliki ketergantungan yang cukup tinggi terhadap potensi dan kondisi sumber daya laut (Pakpahan, dkk 2006).

Perkembangan wilayah pesisir menimbulkan berbagai macam persoalan, di antaranya adalah kebutuhan akan perumahan dan 
permukiman. Rumah sebagai kebutuhan dasar pokok manusia tidak dapat diartikan dari aspek fisik bangunan saja, tetapi lebih lanjut dalam perkembangannya juga memiliki arti yang lebih luas, termasuk dalam fungsi ekonomi dan sosial budaya penghuninya.

Pertumbuhan penduduk di wilayah pesisir Kota Makassar tidak hanya mengakibatkan kepadatan penduduk yang semakin tinggi, tetapi berpengaruh juga terhadap munculnya permukiman kumuh yang ada di pesisir pantai maupun sepanjang sungai. Permukiman kumuh merupakan suatu permukiman yang sangat padat yang dicirikan oleh kondisi lingkungan yang kurang layak huni serta fasilitas yang jauh dari kata memadai.

Pada umumnya kawasan permukiman kumuh didiami oleh kaum urban yang tingkat kepadatan yang tinggi dengan rata-rata penduduknya bekerja di sektor informal. Ciri utama ekonomi penghuninya adalah bermata pencaharian tidak tetap sehingga cenderung memilih bertempat tinggal di lokasi-lokasi yang dekat dengan pusat kegiatan ekonomi yang kebanyakan berada di pusat kota. Menurut Atika (2014) permukiman kumuh dapat dibedakan menjadi antara lain:

1. Permukiman kumuh nelayan

2. Permukiman kumuh dekat pusat kegiatan sosial ekonomi

3. Permukiman kumuh pusat kota

4. Permukiman kumuh rawan bencana

5. Permukiman kumuh daerah tepian sungai

\section{Metode}

Analisis ini menggunakan metode induktif-kualitatif dengan pendekatan fenomenologi. Analisis data disusun berdasarkan informasi empiris yang peneliti temukan di lapangan melalui observasi maupun wawancara mendalam. Adapun aspek yang akan dianalisis dalam penelitian ini adalah awal terbentuknya permukiman nelayan Lette dan sejarahnya dari awal hingga sekarang, deskripsi terkait lokasi penelitian maupun fakta empiris berupa unit-unit informasi yang nantinya peneliti temukan di lapangan

\section{Unit Amatan}

Unit amatan di Permukiman Nelayan Lette, Kecamatan Mariso, Kota Makassar, Provinsi Sulawesi Selatan. Unit amatan meliputi pemanfaatan ruang, sosial, kultur, dan ekonomi yang terjadi dalam kehidupan bermukim nelayan Lette.

\section{Unit Analisis}

Unit analisis berupa ruang, kegiatan dan pelaku yang ada di permukiman nelayan Lette, nantinya tiap-tiap informasi yang diperoleh di lapangan bersumber dari wawancara. Dalam hal ini beberapa warga yang diwawancarai dapat memiliki informasi yang sama ataupun berbeda.

\section{Analisis Data}

Data dari penelitian ini yaitu pemanfaatan ruang, sosial, kultur, dan ekonomi yang terjadi dalam kehidupan bermukim nelayan Lette. Data terkait pemanfaatan ruang/ spasial merupakan data dari citra satelit dari tahun 2000 hingga 2016. Data spasial tersebut dibandingkan sehingga diketahui perubahan spasialnya. Data terkait sosial, kultur, dan ekonomi masyarakat di permukiman nelayan Lette didapatkan dengan survey primer dengan pendekatan fenomenologi dengan menggunakan analisis kualitatif.

\section{HASIL DAN PEMBAHASAN Sejarah dan Tradisi Nelayan Lette}

Lette adalah Bahasa Makassar yang artinya "pindah", menurut sejarahnya dahulu Lette adalah tanah rawa (rawa-rawa) di pinggiran/pesisir Makassar. Warga pertama yang ada di daerah ini adalah orang (warga) Galesong (salah satu kecamatan di Kabupaten Takalar) diikuti orang (warga) Jeneponto (daerah kabupaten yang berbatasan langsung dengan Kecamatan Galesong di sebelah utara). Migrasi ini juga diikuti oleh beberapa orang (warga) dari pulau di sekitarnya, hingga kini latar belakang warga (baik dari etnis, asal daerah, kondisi sosial, kondisi ekonomi) sudah bermacam-macam dan membuat kawasan ini semakin padat. 
Masyarakat Bugis dan Makassar sangat terkenal sebagai pelaut yang ulung secara turun temurun yang bermula pada nenek moyangnya, transformasi budaya dalam dunia pelayaran tidak pernah berhenti dilaksanakan. Aktivitas pelayaran mengalami perubahan dan perkembangan dari mulai mempergunakan perahu kayu dengan dayung sebagai kayuhnya sampai perahu kayu yang munggunakan layar, sedangkan saat ini, perahu sudah menggunakan mesin sebagai penggeraknya.

Di dalam tradisi Bugis-Makassar ada istilah di dalam melaut yang di kenal dengan "passompe" yang diartikan sebagai pelaut. Kebanyakan passompe ini telah memiliki banyak pengalaman dalam berlayar dan pengetahuan tentang ilmu astronomi dan oceanologi tradisional. Patokan dalam berlayar adalah gejala-gejala alam dengan penglihatan. Selain pengetahuan dan pengalaman mereka dalam dunia pelayaran, mereka juga percaya kalau ada yang menjadi penguasa laut, mereka percaya dan mengganggap bahwa yang menjadi penguasa laut itu Nabi Hiderek (Nabi khaidir) dalam hal ini pikiran mereka sangat terikat pada Nabi Khaidir. Masyarakat nelayan Lette menganggap bahwa Nabi Khaidir hidup di air dan darat. Hanya saja karena perkembangan zaman dan modernitas kepercayaan yang sudah menjadi tradisi adat ini sudah hilang dan jarang di adakan prosesinya sehingga hanya nelayan-nelayan tertentu saja yang masih mempercayainya.

Komunitas nelayan patorani memiliki pattern tingkah laku yang berbeda dari nelayan lain yang mencerminkan kebudayaan mereka. Kepercayaan terhadap makhluk gaib yang dipercaya memegang kekuasaan di laut salah satunya diwujudkan dalam bentuk ritual. Mereka sering melakukan beberapa ritual yang mereka anggap bahwa dengan diadakannya ritual tersebut, maka akan mendatangkan kebaikan, sebaliknya mereka yang tidak melakukan ritual yang ada akan mendapatkan bencana baik berupa bencana alam maupun berupa penyakit. Hal ini lah yang masih dipercaya oleh sebagian besar masyarakat Galesong, sehingga nelayan patorani yang telah tua tetap menghimbau anak cucu laki- laki mereka untuk menjadi nelayan patorani dan tetap memertahankan ritual yang ada

\section{Perubahan Spasial}

Kondisi wilayah pesisir dan pantai Tanjung Bunga telah mengalami perubahan yang dahulunya adalah wilayah perairan sekarang sebagian besar wilayahnya berubah menjadi daratan. Perubahan ini terjadi karena adanya proses reklamasi pesisir dan pantai yang sedang berlangsung di wilayah Tanjung Bunga ini. Perubahan perairan menjadi daratan di wilayah Tanjung bunga ini terjadi secara bertahap. Perubahan ini berlangsung mulai dari tahun 2000, 2004, 2006, 2007, 2009, 2016 (Gambar 2 dan Gambar 3). Berikut ini adalah gambar tahapan perubahan yang terjadi di wilayah pesisir dan pantai Tanjung Bunga.

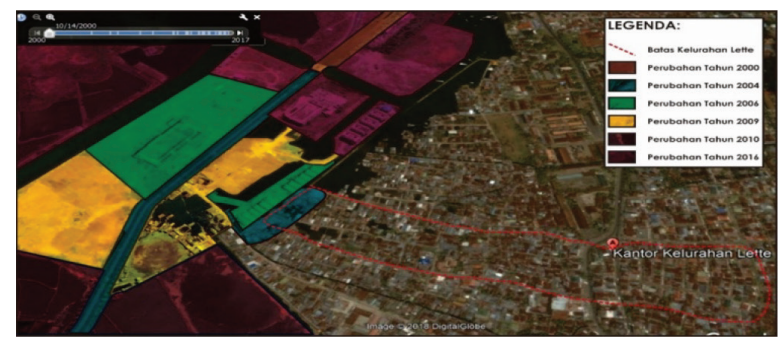

Gambar 2.

Overlay Perubahan Spasial Tahun 2000-2016 Sumber: Citra Google Earth, (2017)

Pada Tahun 2000 adalah kondisi awal permukiman nelayan Lette sebelum di relokasi. Pada kondisi ini menggambarkan Jalan Metro Tanjung Bunga baru separuh terbangun yang menyisakan rencana jembatan di ujung jalannya. Belum terjadi penimbunan di lokasi permukiman masyarakat nelayan Lette. Dermaga parkir perahu masih berupa pondasipondasi kecil di depan permukiman warga. Masih terlihat genangan air laut yang berada di antara permukiman nelayan Lette dan akses melaut masih tidak terbatas.

Pada Tahun 2004 tergambar kondisi Jalan Metro Tanjung Bunga sudah utuh terbangun yang menyambungkan jalan penghibur Losari dengan daratan Tanjung Bunga yang berada di seberangnya. Di kondisi ini juga menggambarkan sudah terjadi penimbunan lahan di permukiman nelayan Lette tepatnya di 


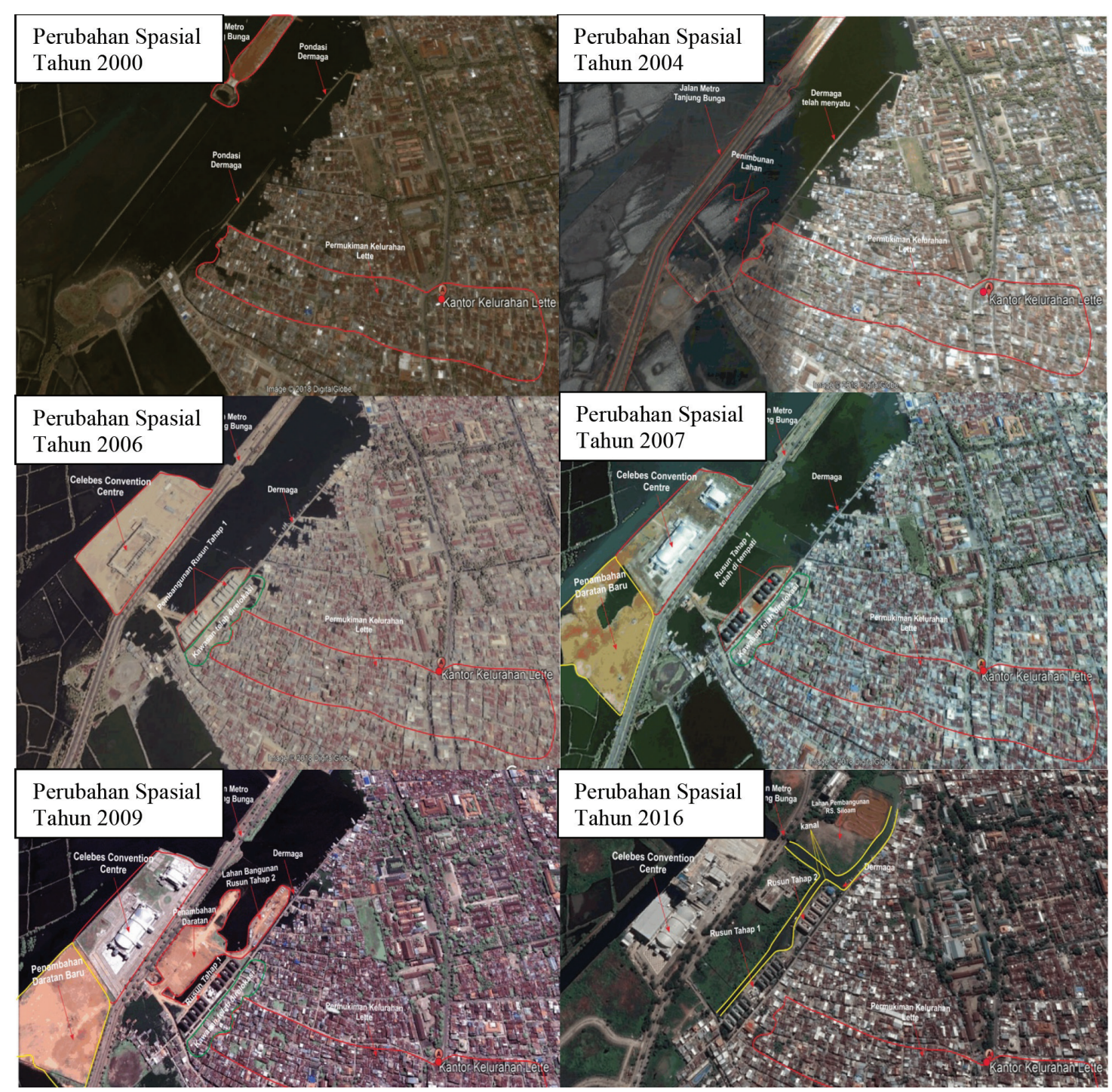

Gambar 3.

Peta Perubahan Spasial Tahun 2000-2016

Sumber: Citra Google Earth, (2017)

bagian selatan dari permukiman, tetapi masih terlihat genangan air laut yang menggenangi di sebagian permukiman. Kondisi dermaga paling selatan kini sudah menyatu dengan timbunan dan menjadi daratan,di kondisi ini juga belum ada proses relokasi warga.

Pada Tahun 2006 kondisi yang berbeda dari gambar sebelumya, yaitu sudah ada timbunan yang membentuk daratan di daerah barat Jalan Metro Tanjung Bunga yang sedang dalam perencanaan pembangunan gedung Celebes Convention Centre. Terlihat struktur pondasi bangunan yang sudah jadi untuk pembangunannya sementara di daerah permukiman nelayan Lette timbunan di daerah selatan permukiman warga yang dulunya adalah dermaga sekarang telah menjadi daratan dan sudah terbangun perencanaan rusun tahap pertama, yaitu 2 (dua) twin blok rusun dengan jumlah unit yang akan di bangun sebanyak 288 unit. Warga yang tinggal di pinggiran pantai telah direlokasi dan menunggu proses pemindahan dari permukiman lama ke rusun.

Pada Tahun 2007 terlihat kondisi pembangunan rusun tahap pertama sudah selesai dan warga nelayan Lette sudah bermukim di rusun, terlihat juga bangunan Celebes Convention Centre telah selesai dibangun. Jumlah daratan yang berada di bagian barat 
jalan Tanjung Bunga juga bertambah untuk pembangunan Kota baru. Dikondisi ini dermaga perahu nelayan Lette berpindah ke daerah utara, masih ada terlihat genangan air laut di bagian utara permukiman warga.

Pada Tahun 2009 terlihat adanya penambahan daratan di sebelah utara rusun yang sebelumnya ini adalah lahan untuk membangun rusun di tahap II yang rencananya akan di bangun 288 unit lagi untuk kebutuhan masyarakat nelayan Lette yang sudah direlokasi yang masih belum mendapatkan unit hunian di rusun sebelumnya ini karena jumlah unit di pembangunan rusun awal tidak dapat menampung jumlah Kepala Keluarga (KK) yang telah direlokasi yaitu $576 \mathrm{KK}$. Terlihat juga penambahan daratan yang berada di depan rusun yang sudah terbangun pembangunan ini membuat parkir perahu nelayan semakin ke utara rusun, artinya jarak rusun ke tempat parkir perahu nelayan semakin jauh.

Pada Tahun 2016 tergambar proses pembangunan rusun tahap II telah selesai dan warga sudah direlokasi ke rusun. Di kondisi ini terlihat dermaga yang dulunya adalah tempat parkir perahu nelayan berubah fungsi menjadi jalan yang menjadi pembatas antara permukiman yang lama dengan rusun. Terlihat juga ada kanal-kanal yang berada di depan rusun serta belakang rusun, dan di sisi utara rusun yang berfungsi sebagai akses keluar masuk perahu nelayan dari permukiman ke laut. Area dermaga yang dulunya memanjang dari utara ke selatan kini tersisa di bagian utara saja yang berfungsi sebagai dermaga parkir perahu nelayan, terlihat juga di kawasan sekitar telah terbangun bangunan-bangunan baru yang berfungsi sebagai hotel dan kantor. Area lahan Rumah Sakit Siloam juga sudah sepenuhnya tertimbun dan sebagian besar pesisir dan pantai di wilayah ini telah berubah menjadi daratan.

\section{Perubahan Kehidupan di Ruang Pesisir}

Kelurahan Lette merupakan salah satu kelurahan di Kecamatan Mariso yang berada di wilayah pesisir Kota Makassar dulunya menjadi tempat bermukim 2 (dua) etnis yaitu warga dari Galesong dan Jeneponto yang kemudian diikuti oleh warga dari pulau- pulau sekitarnya serta warga dari luar daerah lainya sehingga kini Kelurahan Lette menjadi tempat bermukimnya warga dari berbagai daerah di Kota Makassar dan dari luar Kota Makassar (multi-etnis) yang menjadi satu menjadi Komunitas Kampung Lette. Warga dari Kelurahan Lette dominannya berprofesi sebagai nelayan yang berasal dari Galesong, sementara warga yang berasal dari Jeneponto kebanyakan memilih berprofesi sebagai tukang becak dan buruh bangunan. Wilayah Kelurahan Lette ini dahulunya adalah rawarawa pesisir pantai yang mempunyai potensi laut yang melimpah. Nelayan di daerah ini cukup menggunakan perahu dayung untuk menuju ke wilayah tangkap mereka yang tidak terlalu jauh dari pinggiran pantai dengan menggunakan jaring, tombak, dan panah untuk dikonsumsi sendiri atau di jual di pasar pelelangan ikan atau dikenal sebagai Tempat Pelelangan Ikan (TPI) dan di pinggiran jalan sekitar Tanjung Bunga. TPI di kampung ini adalah TPI Rajawali (dapat dilihat pada Gambar 4) sebagai berikut:

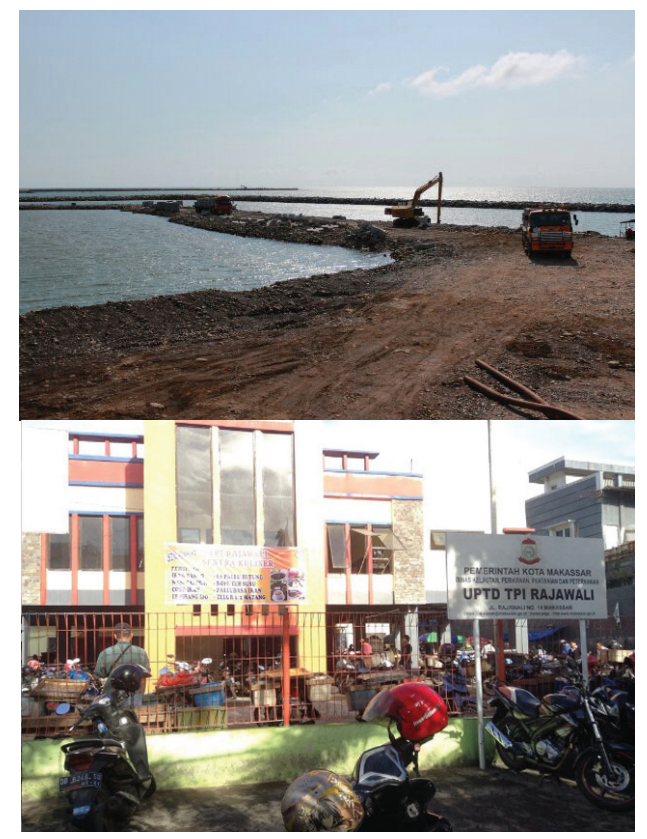

Gambar 4.

TPI Rajawali dan Proses Penimbunan Area Tangkap Nelayan

Sumber: Dokumentasi Peneliti, (2016)

Seiring dengan perkembangan dan pertumbuhan Kota Makassar pembangunan 
terjadi dimana-mana bangunan-bangunan baru bermunculan serta proyek pengembangan jalan yang terus dikembangkan. Pertumbuhan dan perkembangan kota ini memaksa Kota Makassar untuk melakukan reklamasi wilayah pesisir pantai Kelurahan Lette karena kebutuhan akan lahan di perkotaan yang tetap dan terbatas.Wilayah pesisir dianggap area yang sangat berpotensi untuk dikembangkan menjadi lahan baru bagi perkotaan.

Reklamasi pesisir pantai Kelurahan Lette ini dimulai pada tahun 1997 dengan pembangunan Jalan Metro Tanjung Bunga. Tahun 2004 pembangunan Jalan Metro Tanjung Bunga selesai. Pembangunan Jalan Metro Tanjung Bunga ini sangat berdampak besar pada masyarakat Nelayan Lette. Akses melaut mereka menjadi terganggu yang dahulunya mereka bebas melaut dari dermaga menuju area tangkap, sekarang menjadi tertutup oleh pembangunan Jalan Metro Tanjung Bunga. Akibatnya ruang untuk akses keluar dan masuk perahu mereka cukup sedikit yaitu di bawah jembatan Jalan Metro Tanjung Bunga. Reklamasi pantai tanjung bunga juga menimbun sebagian besar daerah baru, kondisi ini membuat akses keluar melaut Nelayan Lette semakin bertambah jauh dan harus melewati jembatan ke-2 (dua) yang terbangun menjadi Jalan Metro Tanjung Bunga di sisi paling barat Tanjung Bunga.

Menurut sebagian besar Nelayan Lette akses keluar dan masuk perahu yang berada di bawah jembatan ini terlalu sempit hanya seukuran satu perahu besar yang memiliki penyeimbang untuk melewatinya dan jika ada dua perahu yang melintas salah satunya harus mengalah ini terlalu sulit untuk mereka karena perahu tidak memiliki rem saat mau berhenti walaupun sudah dimatikan mesinnya perahu masih tetap jalan dan memungkinkan terjadi tabrakan sesama perahu.

Di akses keluar dan masuk perahu ini sering terjadi pendangkalan dan adanya sedimentasi akibat dari tanah timbunan dan sampah masyarakat yang terbawa melalui kanal yang bermuara ke jalur akses keluar dan masuk perahu. Di saat air laut surut tak jarang baling-baling perahu menjadi macet bahkan patah akibat terkena dasaran tanah/ pasir timbunan ataupun sampah masyarakat yang masuk ke jalur keluar masuk perahu ini. Tidak jarang di area keluar dan masuk perahu ini sering dilakukan pengerukan untuk mengurangi pendangkalan. Hal ini menjadi faktor pendorong perubahan ruang pesisir (dapat dilihat pada Gambar 5).

Hal ini diperparah dengan masalah yang baru muncul di area dermaga tempat parkir perahu, yaitu sirkulasi dermaga menjadi masalah baru bagi Nelayan Lette karena dermaga terlalu sempit untuk sirkulasi keluar dan masuk perahu yang mempunyai bodi dan lambung yang besar. Dermaga merupakan fasilitas nelayan yang berfungsi sebagai tempat sandar perahu/tempat parkir perahu, selain jalur akses keluar masuk melaut dermaga sangat dibutuhkan oleh nelayan sehingga perlu adanya perencanaan khusus agar dermaga dapat difungsikan dengan maksimal dan mengakomodasi kegiatan nelayan.

Reklamasi juga menimbun area pantai yang menjadi wilayah tangkap ikan mereka sehingga mereka harus mencari wilayah tangkap ikan yang baru tak jarang mereka harus sampai ke wilayah tangkap kabupaten lain untuk mencari ikan. Selain wilayah tangkap ikan mereka yang berubah semakin jauh, waktu-waktu melaut mereka secara otomatis berubah dan butuh modal tambahan untuk bahan bakar melaut yang menambah beban mereka saat akan pergi melaut.

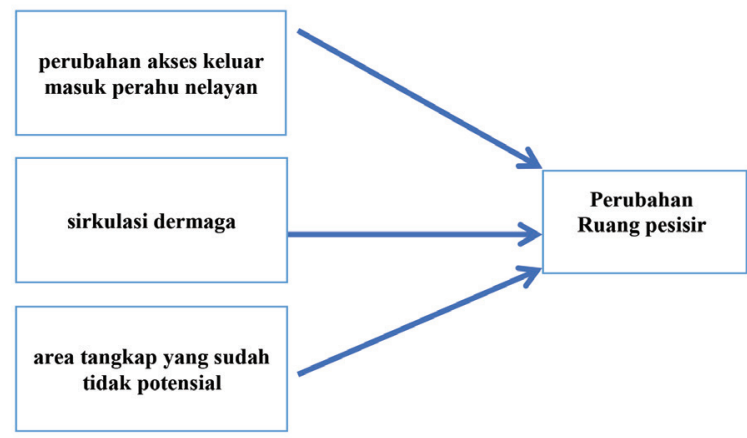

Gambar 5.

Faktor Pendorong Perubahan Ruang Pesisir Sumber: Analisis, (2017) 


\section{Perubahan Ruang Permukiman}

Kelurahan Lette adalah salah satu wilayah di Kecamatan Mariso yang dominan masyarakatnya bekerja sebagai nelayan dan bermukim di wilayah pesisir pantai Kota Makassar yang dikenal sebagai komunitas Nelayan Lette. Pada tahun 2006 Kelurahan Lette mengalami dampak dari reklamasi di sebagian besar wilayah pesisirnya yang dulunya adalah tempat parkir perahu yang kemudian merambat ke permukiman mereka yang mengharuskan mereka untuk direlokasi ke tempat yang baru yakni rumah susun, lokasi rumah susun yang akan menjadi tempat tinggal mereka tidak begitu jauh dari tempat tinggal asal hanya berjarak 30 meter.

Rumah susun ini sangat berbeda dengan kondisi di permukiman awal tempat tinggal mereka yaitu menyebar secara horizontal di pesisir pantai. Hal ini banyak berdampak pada warga pada saat tinggal di rumah susun yang bentuk permukimannya vertikal. Contohnya kegiatan pada permukiman awal seperti memasak, mencuci, mandi, dan buang air, keterbatasan sarana, dan prasarana merupakan kendala sehingga warga memilih melakukan aktivitas domestik di luar rumah karena umumnya sarana dan prasarana di permukiman lama berfungsi sebagai milik bersama, sementara ruang dalam rumah kebanyakan difungsikan sebagai tempat untuk menyimpan peralatan melaut dan peralatan rumah tangga lainnya. Hal ini tentunya berbeda dengan kondisi di rumah susun yang menjadi tempat tinggal baru mereka hampir semua aktivitas ruang domestik dilakukan di dalam hunian, seperti memasak, mencuci, mandi, dan buang air karena sarana dan prasarana aktivitas ruang domestik di rusun telah tersedia di setiap unit hunian dan tidak lagi berfungsi sebagai milik bersama.

Pemanfaatan ruang spasial di permukiman lama pada umumnya digunakan sebagai sarana penyimpanan alat-alat rumah tangga, tempat gantungan pot bunga, dan tempat memelihara hewan ternak. Di Lingkungan permukiman lama mereka ini kebanyakan memanfaatkan spasial depan rumah karena permukiman yang dibatasi oleh saluran pembuangan yang cukup lebar di depan rumah yang dapat di manfaatkan untuk memenuhi aktivitas dan kebutuhan ruang lainnya yang tidak dapat di lakukan di ruang dalam rumah mereka karena keterbatasan ruang. Masyarakat Nelayan Lette di permukiman lama mempunyai kebiasaan berinteraksi sosial hampir setiap hari dengan tetangga-tetangga di sekitarnya dengan memanfaatkan teras, area depan rumah dan bale-bale. Berbeda dengan kondisi ini berbeda dengan warga yang berada di rumah susun mereka memanfaatkan ruang spasial depan hunian sebagai ruang ekonomi semata, dengan memanfaatkan selasar yang berada di depan unit hunian dan ruang lantai 1 (satu) yang berfungsi sebagai tempat parkir. Sebagian dari penghuni rusun yang dahulu adalah nelayan telah berganti profesi menjadi tukang ojek dan buruh bangunan di daerah pengembangan Kotabaru di Kawasan Metro Tanjung Bunga.

Budaya Bale-bale masih terbawa sampai ke rumah susun hanya saja perilaku sosial di rumah susun cenderung terbatas karena di rumah susun warga hanya lebih sering untuk berhubungan dengan tetangga terdekatnya yang satu lantai sementara hubungan dengan warga yang berbeda lantai cenderung berkurang, berbeda dengan kondisi di permukiman nelayan yang dahulu, mereka akrab dengan tetanggatetangganya yang cukup jauh sekalipun.

Faktor pendorong perubahan ruang permukiman di Permukiman Nelayan Lette yaitu aktivitas domestik, pemanfaatan ruang spasial, dan budaya bale-bale. Faktor pendorong perubahan ruang Permukiman Nelayan Lette dapat dilihat pada Gambar 6 sebagai berikut:

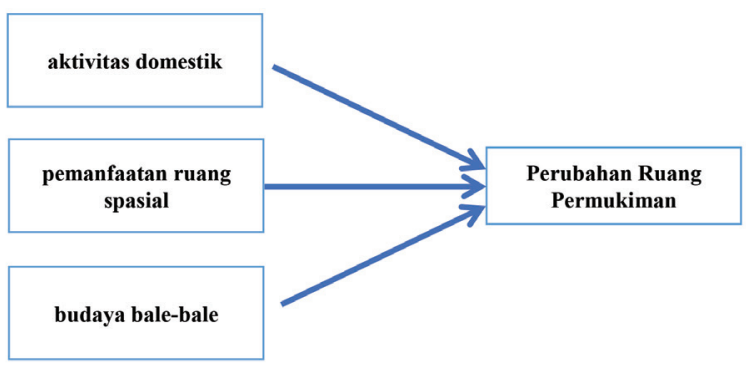

Gambar 6.

Faktor Pendorong Perubahan Ruang Permukiman Sumber: Analisis, (2017) 
Kawasan Bisnis, Wisata, dan Hiburan

Di kawasan reklamasi Pantai Tanjung Bunga lahir pusat-pusat bisnis wisata, hiburan dan komersil, sejak adanya reklamasi pantai untuk pembentukan kota baru, pusat-pusat perbelanjaan seperti Trans Studio Mall, GTC Mall, dan wisata pantai menjadi daya tarik di kawasan ini, pusat-pusat bisnis dan hiburan serta wisata yang banyak terdapat di kawasan ini dengan pekerja dan karyawan yang selalu hilir mudik dengan jumlah yang mencapai ratusan pekerja menjadikan Jalan Metro Tanjung Bunga ramai dilewati kendaraan tidak terkecuali di hari-hari libur aktivitas-aktivitas lain di kawasan ini menjadi meningkat.

Fenomena ini membuka terbukanya peluang usaha-usaha kecil dan jasa yang kemudian dimanfaatkan oleh masyarakat nelayan di Kelurahan Lette. Oleh karena itu, banyak ditemui warung makan/sembako serta jasa tambal ban, penjual bensin eceran, tukang ojek, dan becak/becak motor yang berada di sekitar Jalan Metro Tanjung Bunga, jalan poros rusun, dan jalan lorong 300 yang merupakan jalan alternatif ke jalan rajawali dan sekitarnya.

Tidak heran jika sebagian masyarakat Lette yang dulunya adalah nelayan beralih profesi melihat potensi dari kawasan pusat bisnis, wisata dan hiburan ini selain faktor ekonomi, pekerjaan nelayan sudah tidak dapat memenuhi kebutuhan sehari-hari mereka karena wilayah tangkap ikan mereka yang berubah menjadi jauh dan kurangnya modal untuk melaut di kondisi yang sekarang ini, tak banyak dari mereka sudah menjual perahunya sebagai modal untuk membeli motor berganti profesi menjadi tukang ojek atau membuka kios pulsa.

Berbagai permasalahan sudah dihadapi masyarakat nelayan Lette, tetapi hal ini tidak mempengaruhi semangat mereka untuk masih menggeluti pekerjaan sebagai nelayan. Sementara nelayan yang lain telah beralih profesi karena kondisi sudah tidak potensial untuk menjadi nelayan semestinya ini menjadi perhatian pemerintah daerah untuk menyelesaikan permasalahan yang sedang dihadapi nelayan dengan program pemberdayaan dan peremajaan fasilitas nelayan serta program pelatihan bagi masyarakat nelayan Lette. Pada dasarnya setiap program yang bersentuhan langsung dengan masyarakat akan berdampak pada norma serta budaya nelayan Lette. Demikian pula dengan kelestarian lingkungan laut, begitu juga dengan pantai yang menjadi sumber utama mata pencaharian nelayan. Kehidupan nelayan terutama pada lapisan buruh dalam kegiatan penangkapan ikannya tergantung pada hubungan dengan juragan (pemiliki modal dan kapal). Hal itu karena kekurangan modal atau finansial yang kurang memadai. Kekurangan modal tersebut semakin menambah beban, tantangan serta persaingan yang besar dalam pemanfaatan sumberdaya laut. Di satu sisi nelayan buruh dengan kemampuan dan keterampilan menangkap ikan yang merupakan potensi, tetapi di sisi lain tidak adanya modal merupakan kendala mengingat wilayah laut adalah wilayah terbuka yang dapat dimanfaatkan oleh siapa saja yang memiliki kemampuan untuk mengolah sumber daya alam yang ada di dalamnya. Tekanan pembangunan dan perubahan ruang pesisir sebagian besar di daerah pesisir permukiman nelayan Lette menjadi masalah dan berdampak besar terhadap berubahnya mata pencaharian nelayan. Perubahan ini terjadi pada masyarakat nelayan Lette dengan tidak adanya koperasi nelayan sebagai pemberi modal mereka melaut dan berkurangnya komunitas nelayan yang dahulu sudah terbangun di masyarakat nelayan Lette. Bukan itu saja program bantuan yang di nilai kurang tepat sasaran dan kepedulian pemerintah menangani permasalahan mereka.

Dari munculnya ruang ekonomi baru dan aktivitas informal nelayan, maka hal ini menjadi faktor penyebab munculnya kawasan bisnis, wisata, dan hiburan. Faktor pendorong kawasan bisnis, wisata, dan hiburan dapat dilihat pada Gambar 7 sebagai berikut: 


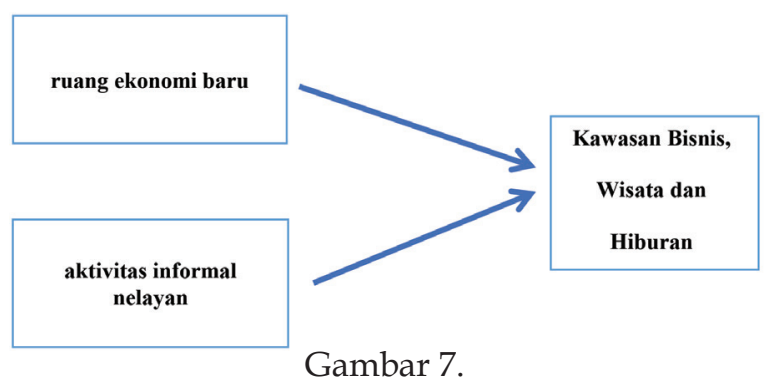

Faktor Pendorong Kawasan Bisnis, Wisata dan Hiburan

Sumber: Analisis, (2017)

\section{SIMPULAN}

Simpulan dari penelitian ini bahwa sejak dilakukannya reklamasi di Kelurahan Lette Kecamatan Mariso terjadi perubahan kegiatan meruang masyarakat nelayan Lette yaitu perubahan wilayah tangkap ikan, jam, dan waktu-waktu melaut, perubahan kegiatan domestik dan pemanfaatan ruang spasial, perubahan kultur, sosial, dan ekonomi nelayan Lette.

Faktor yang mendorong perubahan spasial, kultur, social, dan ekonomi Nelayan Lette didorong oleh beberapa hal sebagai berikut: pertama adalah perubahan ruang pesisir, akses keluar masuk perahu dan fasilitas dermaga yang dibangun kurang memadai dan hilangnya wilayah tangkap ikan serta rusaknya lingkungan sekitar area penangkapan ikan karena reklamasi, menyebabkan nelayannelayan tidak lagi leluasa melakukan aktivitasnya, wilayah tangkapan semakin jauh, sehingga modal yang dibutuhkan untuk melaut menjadi lebih tinggi dan merubah waktu-waktu melaut mereka. Kedua adalah perubahan ruang permukiman, merubah aktivitas domestic, dan pemanfaatan ruang spasial serta kultur yang ada di permukiman lama dan kesulitan ekonomi akibat menurunnya jumlah penghasilan dari aktivitas sebagai nelayan menyebabkan nelayan harus berupaya mencari sumber pendapatan lain.
Ketiga adalah kawasan pusat bisnis, wisata dan hiburan, membuka ruang-ruang ekonomi baru, memanfaatkan peluang ekonomi yang tercipta dikawasan reklamasi serta membuka peluang kegiatan-kegiatan informal yang mendukung adanya perubahan pekerjaan lainnya.

\section{DAFTAR PUSTAKA}

Atika, O. 2014. Peremajaan Permukiman Kumuh Dengan Pendekatan "Community Based Development" di Bantaran Sungai Cisadane Kawasan Panaragan Kota Bogor. Tesis.

Dadi, D.,H. Azadi., F. Serbeta., K. Abebe., F. Taheri., dan T. Stellmacher. 2016. Urban Sprawl and Its Impacts on Land Use Change in Central Ethiopia. Urban Forestry and Urban Greening 16: 132-141.

Ewing, R., S. Hamidi., J.B. Grace., dan Y.D. Wei. 2017. Does Urban Sprawl Hold Down Upward Mobility? Lanscape and Urban Planning 48: 80-88

Giyarsih, S.R. 2017. Regional Management of Areas with Indications of Urban Sprawl in the Surrounding Areas of Universitas Muhamadiyah Yogyakarta, Indonesia. Indonesian Journal of Geography 49 (1): 35-41.

Ihsan, Sabir. 2012. Role of Participatory Rural Appraisal in Community Development. International Journal of Acedemic Research in Business and Social Sciences 2 (8): 25-38.

Oueslati. W., S. Alvanides, dan G.Garrod. 2015. Determinants of Urban Sprawl in European Cities. Urban Studies 52 (9) : 1594-1614.

Pakpahan, H. T., Richard., W. E. Lumintang, dan Susanto, D. 2006. Hubungan Motivasi Kerja Dengan Perilaku Nelayan Pada Usaha Perikanan Tangkap, Jurnal Penyuluhan 2 (1) : 2634. 